\title{
Czesław Miłosz i Walt Whitman: przekład jako prawdziwa obecność
}

Dynamikę rozwojową poezji Czesława Miłosza (i jego twórczości w ogóle) można by opisać jako stopniowe wyciąganie wniosków $\mathrm{z}$ niepożądanych konsekwencji stwierdzonego przez George'a Steinera w słynnej książce Real Presences zerwania przymierza między światem a językiem, stanowiącego zdaniem autora „definicję nowoczesności” ". Zerwanie to było (nieuniknionym?) następstwem ujednolicenia wszystkich aspektów bytu jako doznawanych treści świadomościowych ${ }^{2}$. Zatem na przełomie XIX i XX w. samo pojęcie (samo)świadomości jako czynnika integrującego te rozmaite treści uległo (auto)destrukcji na rzecz koncepcji tekstu w najszerszym tego słowa znaczeniu, przy czym również medium wyrażające ową nieufność - język - straciło swą przejrzystość. Otóż wydaje się, że Miłosz polemizował z tym (post)modernistycznym impasem na przestrzeni samej poetyki (post)modernistycznej, sprowadzając go ad absurdum, wykazując jego wewnętrzną niespójność. Posługiwał się w związku z tym na wielką skalę niezbyt przez siebie lubianym (bo typowo modernistycznym) zabiegiem konstrukcyjnym ironii sytuacyjnej (traktując ją jako zło konieczne) 3 . Dopiero pod koniec lat 80 .

I Zob. G. Steiner, Real Presences, London 1989, s. 93.

${ }^{2}$ Por. ibidem, s. 70.

3 Steiner zwraca uwagę, że tacy tradycyjni sceptycy jak Montaigne i Hume byli „mistrzami stylu, doskonale zadomowionymi w domostwie języka” (ibidem, s. 92: "thorougly at home in the house of language”). Owi paradoksalni wyznawcy zachodniego logosu wychodzili więc z założenia, że sensowność wypowiedzi lub sądów nie zależy od rozstrzygnięcia pytania o (nie)istnienie przedmiotu, do którego one odsyłają, ani podmiotu je wypowiadającego. W Miłoszowym wierszu Ars poetica? sytuacja ta ulega odwróceniu. Język w tym utworze nie jest domostwem, lecz żywiołem tajemniczym, moralnie dwuznacznym, czyli swoistym antylogosem nawiedzającym dom, którego mieszkaniec, podkreślając obcość tego żywiołu, nie przestaje nim się posługiwać: „Jaki rozumny człowiek zechce być państwem demonów, / Które rządzą się w nim u siebie, przemawiając 
Miłosz doszedł do wniosku, że można znów bezpośrednio mówić (pisać) o świecie (doskonałym przykładem tego zwrotu w stronę realizmu są jego późne tomiki poetyckie Dalsze okolice, Na brzegurzeki $\mathrm{i}$ To). W latach 90. poeta dostrzegał podobną bezpośredniość podejścia do rzeczywistości w najnowszej prozie polskiej reprezentowanej przez powieść Tomka Tryzny Panna nikt. Ów „postmodernizm alla polacca” wartościował Miłosz pozytywnie ze względu na intencję autorską - na ogół ocenianą przez niego w kategoriach moralnych odwołujących się do realnie istniejącej „idei” Dobra - nawiązywał tu więc do bogatej spuścizny filozofii (neo)platońskiej utożsamiającej Prawdę, Dobro i Piękno4. Przepaść między instancją autorską jako efektem tekstowym a autorem „biograficznym” została w końcu przezwyciężona.

Droga do odzyskania instancji autorskiej jako wiarygodnego centrum świata przedstawionego $\mathrm{w}$ dziele o charakterze autobiograficznym była jednak długa i zawiła. Warunkiem prostoty poezji sędziwego poety była radykalizacja antynomii rozdzierających podmiot modernistyczny. Twórczość Miłosza z lat 60 . i 70. (począwszy od poświęconego Wilnu poematu Miasto bez imienia, a kończąc na tomiku Nieobjęta ziemia) stanowi etap przejściowy pomiędzy ironicznym (anty)modernizmem utworów takich jak Świat poema naizene i Traktat poetycki - z jednej strony - a „realistyczną" poetyką starego Miłosza $-\mathrm{z}$ drugiej. Właśnie na tym etapie swojej twórczości poeta utworzył formę „poematu hybrydycznego", którego najznakomitszymi realizacjami są: Gdzie weschodzi stońce $i$ kędy zapada oraz Osobny zeszyt (pierwowzorem tego gatunku są oczywiście Eliotowskie poematy Ziemia jałowa i Cztery kwartety). Ciekawe, że tekst kończący ten okres, a mianowicie Nieobjęta ziemia, wyłamuje się już z ram gatunku, choć sam autor wyraża nadzieję, że „pod powierzchnią nieco dziwacznej różnorodności czytelnik rozpozna prawdziwą

mnóstwem języków, / a jakby nie dosyć im było skraść jego usta i rękę,/ próbują dla swojej wygody zmieniać jego los? [...] bo dom nasz jest otwarty, we drzwiach nie ma klucza, / a niewidzialni goście wchodzą i wychodzą" (C. Miłosz, Wierszee, t. 3, Kraków 2003, s. 78-79).

4 Por. wiersz Zaklęcie z tomu Miasto bez imienia. Trzeba jednak zwrócić uwagę na to, że tytuł tego wiersza wprowadza ironiczny dystans do jego treści (może też odwrotnie). W epoce relatywizującej zdolność człowieka do ujmowania świata jako „rzeczywiście istniejącego” poznawczą energię rozumu można widocznie wypowiedzieć tylko w formie magicznej inkantacji. Ważne jest tu przede wszystkim to, że owa etycznie zabarwiona zdolność poznawcza zakłada istnienie wspólnoty ludzkiej - „On nie zna Żyda ni Greka, niewolnika ni pana, / W zarząd oddając nam wspólne gospodarstwo świata” (C. Miłosz, Zaklęcie, w: Wierszee, t. 3, s. 77). Na pewno nie jest sprawą przypadku, że wiersz ten sąsiaduje z równie ironicznym (w tym sensie, że ironizuje własną ironię, znosząc i przeobrażając ją w powagę) utworem Ars poetica? 
jedność" tego utworu wiążącą się z poszukiwaniem wspomnianej już „formy bardziej pojemnej” .

Ten tomik poemat jest więc kolejną próbą uporania się $\mathrm{z}$ (post)modernistycznym impasem. Literatura spod jego znaku była bowiem niezdolna ująć „twardą i drapieżną” rzeczywistość, która nas otacza ${ }^{6}$. Sprowadzała ją w swoich dziełach do „szyderczej $[. .$.$] mieszanki europejskich tradycji”, gdzie „przepla-$ tają się" różne motywy (w taki sposób charakteryzował Erich Auerbach powieść Ulysses Jamesa Joyce’a; Miłosz przytacza tę ocenę $\mathrm{z}$ aprobatą $\mathrm{w}$ eseju pod znamiennym tytułem Rzeczywistość $c^{7}$. Inne powieści (cytuję znów - za Miłoszem - Auerbacha), „[posługując] się wielostronnymi odbiciami w świadomości, przeważnie pozostawiają czytelnika z uczuciem beznadziei. Jest w nich często coś zbijającego z tropu, coś mętnego, coś wrogiego rzeczom, jakie przedstawiają" ${ }^{8}$. Czy jednak sam Osobny zeszyt nie jest podróżą „przez galerie luster” " ? Czy nie odbija się w nich świadomość, która nigdy nie jest zdolna w pełni ująć samej siebie? Zwłaszcza relacja między „ja” jako substancją psychiczną a "ja” cielesnym pozostaje "dla mnie” zagadkowa. Czy w obliczu tego rozdwojenia „mojego” własnego „ja” w ogóle może być mowa o tym, by „moja” świadomość dotarła poprzez jakieś obce ciało do świadomości leżącej u podstaw tego ciała?

Ja, świadomość, zaczynam się od skóry

Gładkiej czy też porosłej gajami włosów.

Szczeciniasty policzek, pagórek łonowy, pachwina,

Jedynie moje, choć nie tylko moje.

A w tej chwili inna, jego czy jej świadomość

Bada uważnie własne ciało w lustrze,

Rozumiejąc, że swoje, chociaż własne nie jest.

\section{Czy dotykając jednej cielesności w lustrze,}

Dotykam każdej, znam cudzą świadomość?

Czy wcale nie i ona, niedosiężna,

Poznaje na swój tylko, najwłaśniejszy, ład? [podkr. - A.N.] ${ }^{\text {10 }}$

5 C. Miłosz, Osobny zeszyt, w: Wiersze, t. 3, s. 78.

${ }^{6}$ C. Miłosz, Ogród nauk, Lublin 1991, s. 35.

7 Ibidem, s. 37.

8 Ibidem.

9 C. Miłosz, Osobny zeszyt (1977-1979), w: Wiersze, t. 3, s. 226.

ro C. Miłosz, Nieobjęta ziemia. Śreiadomość, w: Wiersze, t. 4, Kraków 2004, s. 69. Tę samą intuicję Miłosz ujął w Nieobjętej ziemi również dyskursywnie, w postaci „ogólnej prawdy”, odwołując się do „tradycji filozoficznej” (czyli właśnie w ramach dialogu): „Nie jestem, kim jestem. Wymyka mi się moja esencja. Tutaj A nie równa się A. Trwałym osiągnięciem filozofii egzystencji jest 
Wątpliwości tych nie da się rozwiać za pomocą jakiejś ogólnej teorii epistemologicznej. Jednakże sama forma Nieobjętej ziemi, tzn. jawna dialogiczność jej struktury, sugeruje, że mamy tu do czynienia z problemem pozornym. Tomik stanowi bowiem zbiór najrozmaitszych podgatunków, własne wiersze Miłosza przeplatają się z „sentencjami zakreślonymi przy lekturze różnych pisarzy $[\ldots]$, przekładami $z$ innych poetów, zapisami prozą, a nawet listami od przyjaciół, jeżeli dotyczyły niepokojących nas pytań” ${ }^{\text {II }}$. Widać wyraźnie, że również $\mathrm{w}$ tym przypadku Miłosz zwalcza poetykę (post)modernistyczną za pomocą zabiegów wypracowanych przez ten właśnie nurt. Różnica wobec poetyki z czasów cyklu Śrwiat poema naiwene polega zaś na tym, że poeta rezygnuje $\mathrm{z}$ ironii sytuacyjnej. W niniejszym tekście próbuję odpowiedzieć na pytanie, czy w Nieobjętej ziemi udało mu się rzeczywiście przezwyciężyć impas (post)modernistyczny. A jeżeli tak - jaką rolę odgrywały w tym dokonane przez samego Miłosza przekłady poezji Walta Whitmana, których jest w tym tomie aż dwanaście ${ }^{\mathrm{I} 2}$.

Zastanówmy się jednak najpierw nad rodowodem impasu (post)modernistycznego i przedstawmy go w największym skrócie. Jego korzenie sięgają - jak wiadomo - przełomu XIX i XX w. Zwraca na to uwage Miłosz w swojej prywatnej i trochę ironicznej historii polskiej poezji nowoczesnej nakreślonej w Traktacie poetyckim:

Styl nasz, choć jest to przykre, tam się rodzi.

Bzyka pokorna lira wcześnie rano

W mansardzie nad grzechotką tingel-tanglu.

Pieśń eteryczna niby chrobot gwiazd,

Handlarzom i ich żonom niepotrzebna

I ludziom z górskich wiosek niepotrzebna.

Czysta, na przekór smutnym sprawom ziemi ${ }^{\mathrm{I} 3}$.

Główną odpowiedzialność za postępujące w XX w. wyobcowanie poezji z ,życia” ponosiła zdaniem Miłosza „poezja czysta", zainicjowana przez francuskich parnasistów i udoskonalona przez Stéphane’a Mallarmégo, który pragnął „oczyścić język

uświadomienie nam, że nie powinniśmy myśleć o własnej przeszłości jako na zawsze ustalonej, bo nie jesteśmy drzewem ani kamieniem" (C. Miłosz, Nieobjęta ziemia, w: Wiersze, t. 4, s. 120).

II C. Miłosz, Od Autora, w: Wiersze, t. 4, s. 7.

${ }^{12}$ Iskry spodkoła, Cudy, Kawaleria przechodzi rzekę w bród, Biwak na zboczu góry, Do lokomotywy wimie, Wy, zbrodniarze na rozprawach w sadzie, My dwoje, $O$, zyý zarwsze $i$ zawsze umierać, Kiedy ocean życia zabierat mnie wodplywie, Kim ostatecznie jestem, Czy nigy na Ciebie nie przyszła godzina, Ostatnia inwokacja.

I3 C. Miłosz, Traktat poetycki, w: Wiersze, t. 2, s. 177-178. 
plemienia" (tak Thomas S. Eliot parafrazuje w drugim z Czterech kwartetów, Little Gidding, linijkę z sonetu Mallarmégo napisanego z okazji odsłonięcia pomnika Edgara A. Poego: „donner un sens plus pur aux mots de la tribu” ${ }^{14}$ ). Miłosz odrzucał tę linię poezji modernistycznej na rzecz innej zapoczątkowanej przez Valery'ego Larbauda i udoskonalonej przez Apollinaire' ${ }^{\mathrm{I} 5}$. To Apollinaire usiłował napełnić pustkę nowoczesnego, wyalienowanego i dążącego do samowystarczalności „ja” treścią podróży poznawczych w nieznane dotąd strefy ludzkiego doświadczenia (zarówno geograficzne, jak i psychiczne - w tym ostatnim przypadku nawiązał do poetyki Jeana A. Rimbauda). Owej drugiej, „odśrodkowej” linii odpowiada ekspansywna, chłonna postawa podmiotu w poezji amerykańskiego ,wieszcza” - Walta Whitmana $^{16}$ - który na przykład w utworze Passage to India kojarzy historyczne zdarzenie budowy Kanału Sueskiego z mentalną podróżą podmiotu na Wschód. Różnica między duchem a materią okazuje się tu pozorna, ponieważ w rezultacie tej podróży podmiot poznaje (pozna) tajemnice głębsze niż „mądrość pieśni wedyjskich" ${ }^{\text {77 }}$. Otwartości przestrzeni geograficznej odpowiada tu otwartość „ja” na nowe doświadczenia duchowe, dzięki którym człowiek „kąpie się w Bogu” ${ }^{18}$.

Tajemnica Bożej transcendencji (niekoniecznie w sensie dogmatyki chrześcijańskiej) okazuje się warunkiem obcowania człowieka ze światem przez akty samoprzekraczania, przy czym substancjalność obu biegunów tej podstawowej relacji (poprzedzającej wszelką intelektualną refleksję) nie jest zagrożona:

\section{Passage to India!}

Lo, soul, seest thou not God's purpose from the first?

The earth to be spann'd, connected by network,

The races, neighbors, to marry and be given in marriage,

The oceans to be cross'd, the distant brought near,

The lands to be welded together ${ }^{\text {I9 }}$.

I4 „,...] to purify the dialect of the tribe”, T.S. Eliot, Collected Poems 1909-1962, London 1974, s. 218.

I5 Zob. autokomentarz Miłosza do Traktatu poetyckiego, w: Wiersze, t. 2, s. $177-178$.

I6 Wpływ Whitmana na poezję Miłosza został gruntownie zbadany przez Martę Skwarę w artykule The Poet of Great Reality - Czeslaw Milosz's Reading' of Walt Whitman, „Walt Whitman Quarterly Review” 2008, t. 26, nr 1, s. 1-22.

${ }^{17}$ „Passage to more than India! [...] O soul, [...] Soundest below the Sanscrit and the Vedas?". W. Whitman, Passage to India, w: The Complete Poems, Harmondsworth 1986, s. 436.

I8 „Bathe me O God in thee, mounting to thee, / I and my soul to range in range of thee". Ibidem, s. 435.

I9 Ibidem, s. 429. 
Zagadnienie statusu języka jako czynnika pośredniczącego między „ja” i światem, podmiotem i przedmiotem Whitmana nie interesuje. Język w formie poetyckiego „śpiewu” (singing) stanowi dla niego medium całkowicie przejrzyste i znikające w konkrecie relacji poznawczej. W tym sensie Whitman wydaje się jeszcze poetą przednowoczesnym, jeżeli przez poetycką nowoczesność (albo może raczej przez „modernizm”) rozumiemy taką postawę, która postuluje zasadniczą niezgodność między uogólniającymi właściwościami języka (i wszystkich innych kodów porozumienia) a raczej niepowtarzalnymi doświadczeniami indywidualnego ,ja”. Język jest tu więc z konieczności medium alienującym, unicestwiającym to, co stanowi o istocie ludzkiej egzystencji. W najlepszym razie język wyraża „moją” (ale jednak również „niemoją”, bo „Gombrowiczowską") świadomość, że właśnie on, język, „nie przylega do tego, czym naprawdę jesteśmy [...]. I każda moja próba powiedzenia czegoś rzeczywistego kończyła się tak samo, zagnaniem mnie z powrotem w opłotki formy, niby owcy odbijającej się od stada" ${ }^{20}$. Kiedyś, w czasach klasycystycznych, uważano wprawdzie, że owe kody są ponadindywidualnym warunkiem nie tylko ludzkiego porozumienia, lecz także możliwości „indywidualnych” opisów rzeczywistości „poza mną”. Nie sposób bowiem dla każdego konkretnego aktu percepcji świata wypracowywać narzędzi wyrazu dostosowanych do tej a nie innej relacji podmiotowo-przedmiotowej. Poeta nie może więc opisywać jakiegoś momentu bycia-w-świecie zupełnie naiwnie, jakby wyrzucając wszystkie wcześniejsze próby opisu tegoż świata poza nawias. Nie udało się to nawet Joyce'owi w osławionym dziele Finnegan's Wake. Relacja między „ja” a światem zdaje się w związku z tym polegać na akcie wiary (tak przynajmniej uważał Miłosz). Konieczność takiego aktu wiary można sformułować dyskursywnie lub w postaci performatywnej, posługując się opisami świata dokonywanymi przez konkretną osobę, która z drugiej strony nie rezygnuje z prób teoretycznego uzasadnienia możliwości mimesis. Whitman wybrał pierwszą opcję w pewnej „deklaratywnej” notatce, którą chciał prawdopodobnie później rozwinąć w wiersz (notatkę tę Miłosz cytował kilkakrotnie w tekstach eseistycznych ${ }^{2 \mathrm{I}}$ ):

Jestem poetą rzeczywistości,

Twierdzę, że ziemia nie jest echem

Ani człowiek widmem.

${ }^{20}$ C. Miłosz, Nieobjęta ziemia, w: Wiersze, t. 4, s. 32.

${ }_{21}$ Zob. C. Miłosz, Życie na wyspach, Kraków 1997, s. 101. 
Ale że wszystkie rzeczy widziane są prawdziwe.

Świadectwo i białe świtanie rzeczy są równie prawdziwe ${ }^{22}$.

Rzecz jednak w tym, że takie ogólne twierdzenie o istocie relacji między „ja” a światem pozostaje w sferze abstrakcji i tego, co obiecuje, nie co realizuje, na poziomie tekstu. Może właśnie dlatego Whitmanowi nie udało się dokończyć tego wiersza notatki.

Miłosz, który skądinąd doskonale zdawał sobie sprawę z wyobcowujących właściwości języka „poetyckiego" ${ }^{23}$, był od samego początku wielbicielem poezji Whitmana i przełożył na polski wiele jego krótszych utworów (oraz fragment ze słynnej, tylko pozornie wsobnej, Pieśni o sobie samym). Przekłady te to na ogół zwięzłe, uczuciowo zabarwione zapisy egzystencji konkretnych ludzi (niekoniecznie jednostek, równie dobrze może tu chodzić o jaką̧ grupę ludzi, np. żołnierzy północnych Stanów w jednym $\mathrm{z}$ wielu epizodów amerykańskiej wojny domowej ${ }^{24}$ ) namacalnie osadzonych w krajobrazie. Wiersze, o których mowa, powstawały jako zapis właściwie niepowtarzalnych chwil zaślubin podmiotu z przedmiotem. Intensywność więzi „ja” z przyrodą nie różni się przy tym od intensywności jego więzi z (innymi) ludźmi. Podmioty obcują ze sobą w relacji braterskiej opierającej się zarówno na realności świata odbieranego przez zmysły, jak i na substancjalności idei Dobra ${ }^{25}$. Pozytywny stosunek Miłosza do

${ }_{22}$ C. Miłosz, Wypisy z ksiag użytecznyych, Kraków 1994, s. 75.

23 Por. jego „wykład” pt. Spór z klasycyzmem: „Erich Auerbach w swoim głośnym dziele Mimesis zwrócił uwagę na pewien niedostatek rzeczywistości tam, gdzie wkracza konwencja, to znaczy tam, gdzie poeta tworzy możliwie piękny układ z topoi powszechnie znanych i utartych, zamiast próbować nazwać to, co rzeczywiste, ale nienazwane" (C. Miłosz, Świadectwo poezji. Sześć wykładów o dotkliwości naszego wieku, Warszawa 1987, s. 62).

${ }^{24}$ „Wyciągnięci w długą linię pojawiają się, to nikną między zielonymi wyspami./ Suną wężem, broń ich błyska w słońcu - słyszysz, jak dzwoni./ Patrz, srebrna rzeka, w niej bryzgi spod kopyt, konie zatrzymujący się, żeby pić./ Patrz, ogorzali ludzie, każda grupa i każdy z nich jak obraz, mniej gorliwi odpoczywają w siodłach, / Niektórzy wynurzają się na drugim brzegu, inni dopiero wjeżdżają w bród - podczas gdy/ Proporczyki czerwono-niebiesko-śnieżnobiałe/ Wesoło furkoczą na wietrze” (C. Miłosz, Mowa wiąana, Warszawa 1986, s. 218). Wybór tego wiersza wydaje się nieprzypadkowy. Obraz niknących wśród roślinności jeźdźców przypominał Miłoszowi sytuację człowieka otoczonego bujną przyrodą stepów ukraińskich, opisanych już w $M a-$ rii Antoniego Malczewskiego i oczywiście w Stepach akermańskich Adama Mickiewicza.

25 Nie wystarczy więc sformułowanie intencji moralnej jedynie jako postulatu do wypełnienia, chyba że takie ujęcie wchodzi w obręb struktury dialogicznej składającej się na szerszą całość „Księgi”, jak np. w przypadku przekładu pierwszych dwóch zwrotek z jednego ze słynnych hymnów (Das Göttliche) Goethego przytoczonego w Nieobjętej ziemi jako jednej z „epigrafów”: „Człowiek 
poetyki Whitmana zasadza się na sprzęgnięciu wiarygodności opisu $\mathrm{z}$ intencją moralną, przy czym owa intencja zawsze jest przypisana do jakiejś ściśle określonej sytuacji, w której „,ja” odkrywa niby przypadkowo jakiś głębszy sens. Nie jest to jednak przypadkowość prozy modernistycznej analizowana przez Auerbacha w następującym cytacie $\mathrm{z}$ jego najważniejszego dzieła Mimesis (analiza odnosi się do słynnej powieści Virginii Woolf Do latarni morskiej):

Oto właśnie owe znamienne i nowatorskie cechy techniki narracyjnej: przypadkowość okazji, która wyzwala procesy zachodzące w świadomości [...], wydobycie przeciwieństwa pomiędzy czasem „zewnętrznym” i „wewnętrznym”. Owe [...] cechy mają pewien element wspólny - ujawniają postawę pisarza: zajmuje się on teraz o wiele bardziej, aniżeli działo się to dawniej w utworach realistycznych, dowolnymi i przypadkowymi fragmentami rzeczywistości. [...] u Virginii Woolf wydarzenia „zewnętrzne” w ogóle utraciły swą dominację, służą one jedynie wyzwalaniu i uzasadnianiu procesów wewnętrznych, podczas gdy dawniej - a często jeszcze i dzisiaj procesy wewnętrzne służyły przeważnie przygotowaniu i uzasadnianiu doniosłych wydarzeń natury zewnętrznej ${ }^{26}$.

W krótszych utworach Whitmana (ale w pewnym sensie też w Pieśni o sobie samym) procesy wewnętrzne służą nie tyle przygotowaniu „doniosłych wydarzeń natury”, ile raczej ukazaniu, że również „życie wewnętrzne” człowieka jest wydarzeniem właśnie „naturalnym”; inaczej mówiąc: opozycja między „ja” a światem, między substancją psychiczną a materialną, między obszarem wewnętrznym a zewnętrznym okazuje się nieporozumieniem $^{27}$.

$\mathrm{Z}$ formalnego punktu widzenia Whitmanowskie notatki egzystencjalne są oczywiście nie mniej „skonstruowane” niż utwór awangardowy, w którym „obnaża się zabieg” (prijom), ale ta ich „sztuczność” ma się właśnie nie rzucać w oczy. Pod tym względem poetyka notatek egzystencjalnych wydaje się jednak odpowiednikiem pewnych właściwości bardziej realistycznej odmiany prozy modernistycznej, w której - jak widzieliśmy -

niech będzie szlachetny, / Pomocny bliźnim, dobry!/ Bo tylko wtedy jest inny/ Od wszystkich znanych nam istot" (C. Miłosz, Nieobjęta ziemia, w: Wiersze, t. 4, s. 8).

${ }^{26}$ E. Auerbach, op.cit., s. 512-513.

27 Por. krótki wiersz („,inskrypcja”) One's-SelfI Sing: „Of physiology from top to toe I sing, / Not physiognomy alone nor brain alone is worthy for the Muse, I say the Form complete is worthier far [...]" (W. Whitman, One's-Self Sing, w: The Complete Poems, s. 37). 
przypadkowość staje się świadomie zastosowaną zasadą konstrukcyjną ${ }^{28}$.

Do tego zaś, co dzieje się w powieści Do latarni morskiej, zmierzają $\mathrm{z}$ reguły $\mathrm{i}$ inne utwory tego rodzaju; co prawda nie wszystkie $\mathrm{z}$ równie głęboką przenikliwością i $\mathrm{z}$ równym mistrzostwem. Kładzie się w nich nacisk na pierwsze lepsze wydarzenie i wykorzystuje je nie w służbie jakiegoś spójnego planu akcji, ale z uwagi na sam ów epizod; przy tym zaś uwidocznia się coś zupełnie nowego i elementarnego - właśnie pełnia rzeczywistości i głębia życiowa osiągalna $\mathrm{w}$ owym momencie, któremu powierzamy się bez jakiegoś z góry powziętego planu ${ }^{29}$.

Różnica między Whitmana krótkimi notatkami egzystencjalnymi, budowanymi wokół „pierwszego lepszego wydarzenia" (mimesis nie sprowadza się tu wyłącznie do naśladowania lub odzwierciedlenia stanów świadomości), a prozą modernistyczną polega więc na tym, że obrazują odmienne sposoby doświadczenia pełni rzeczywistości. W prozie modernistycznej owo doświadczenie ma charakter prywatny. Wydaje się, że wyklucza obecność innych ludzi w sensie jakiejś konkretnej wspólnoty, do której „my wszyscy” należymy. Whitman zaś, wypowiadając się w pierwszej osobie liczby pojedynczej, wychodzi z założenia, że pełne doświadczenie rzeczywistości zakłada zawsze istnienie wspólnoty. Nie jest to jednak wspólnota opierająca się na pewnych wyraźnie sformułowanych konwencjach poetyckich (tzn. poetyki „normatywnej”) jak w epokach „klasycyzujących”. Wspólnota Whitmanowska ma raczej charakter potencjalny, zasadza się na możliwości dzielenia się „indywidualnymi" doznaniami zmysłowymi, których niepowtarzalna, niejako przypadkowa istota prześwieca przez uogólniający „kod” językowy. Miłosz opowiada się tu oczywiście po stronie amerykańskiego poety, który zaprzeczył istnieniu nieprzekraczalnej bariery między indywidualnym „ja” a innymi ludźmi, czyli - jak ujął to sam Whitman - „masą”: „Siebie-samego [...] prostej osoby oddzielnej,/ A jednak wypowiadam słowo «Demokratyczne», słowo «w Masie»” („One’s self I sing,

${ }^{28}$ Są to $\mathrm{w}$ pewnym sensie doświadczenia epifaniczne, tyle że nie objawiają jakiejś niezapośredniczonej rzeczywistości, lecz „głębszy” sens tej pozornie przypadkowej rzeczywistości zapośredniczony przez pewną „podmiotową władzę”. Pod tym względem poetycka praktyka Whitmana przypomina trochę miłoszowską epifaniczność - zob. R. Nycz, Literatura jako trop rzeczywistości, Kraków 2001, s. 168.

29 E. Auerbach, op.cit., s. 525. 
a simple separate person, / Yet utter the word Democratic, the word En-Masse") $3^{\circ}$.

Miłosz ujął literacką tożsamość specyficznie amerykańskiego „ja”, odwołując się właśnie do poezji Whitmana. Powołuje się na niego explicite w następującym fragmencie ważnego eseju O emigracji do Ameryki tudzieżjakby podsumowanie, który ukazał się w zbiorze Widzenia nad Zatoką San Francisco:

Jeżeli en masse, to nie zaczynam od mego zamku rycerza, chaty chłopa, sklepu mieszczanina, jestem Każdym i muszę siebie określić w powszechnej płynności, wobec zbiorowiska ludzkiego w ruchu złożonego z Każdych. [...] Nie mówię tutaj o żadnym rozpłynięciu się w masie, [...] ale o odniesieniu siebie do innych, osobnych ludzi, tak samo jak ja wtrąconych w pozycję geograficznie chwiejną ${ }^{3 \mathrm{I}}$.

Najbardziej przekonującym symbolem takiej wspólnoty byłaby poezja wielkiego miasta. Właśnie tu zaznacza się najdobitniej odmienność postawy amerykańskiego piewcy Postępu od większości europejskich pisarzy, począwszy od epoki romantyzmu. Whitmanowski Nowy Jork nie jest - jak w prozie modernistycznej - przestrzenią wyobcowania, lecz właśnie tym miejscem, w którym „nasze” wspólne człowieczeństwo ziści się w „darze” i w „miłości”, w „przelotnych błyskach twoich oczu dla mnie". Manhattan zostaje niejako uczłowieczony, stanowi jeden wielki organizm:

Miasto uczt, spacerów, radości,

Miasto, dlatego że ja tam żyłem i śpiewałem, sławne,

Nie twoje festyny, zmienne obrazy, widowiska,

Nie rzędy nieskończone twoich domów, w przystaniach okręty,

Nie pochody uliczne, nie jasne, pełne towarów okna wystawowe,

Nie rozmowy z uczonymi ludźmi, nie udział w świętach i zaba-

wach,

Nie to, Manhattanie, ale dar, miłość

W przelotnych błyskach twoich oczu dla mnie, przechodnia,

Dar, miłość, odpowiedź na moją miłość, to jest dla mnie nagrodą,

Kochankowie, zawsze kochankowie, to jest moją nagrodą ${ }^{2}$.

Wiersz ten doskonale oddaje doświadczenie en masse sformułowane przez Miłosza w poświęconym Whitmanowi eseju

\footnotetext{
$3^{\circ} \mathrm{W}$. Whitman, The Complete Poems, s. 37.

3 C. Miłosz, Widzenia nad Zatoka San Francisco, Kraków 1989, s. 190.

${ }^{2}$ Przekład wiersza cyt. za: C. Miłosz, Ogród nauk, s. 212.
} 
z Widzeń nad Zatoka San Francisco. Nie został jednak włączony do Nieobjętej ziemi. Miłosz przełożył i włączył do Nieobjętej ziemi natomiast inny utwór Whitmana wyrażający apoteozę wspólnoty wielkomiejskiej:

Tam gdzie miejski nieustanny thum śpieszy przez cały dzień, Odchodzę na bok, przyłączam się do patrzących dzieci, zostaję

$\mathrm{z}$ nimi.

$[\ldots]$

Ta scena i jej szczegóły przenika mnie i zostaje we mnie:

Smutny stary człowiek ze spiczastym podbródkiem, w wytartym ubraniu, z szerokim skórzanym pasem na ramieniu,

Ja w nadmiarze, płynny, duch dziwnie wędrujący, teraz tu zatrzymany,

Ta gromadka (niezamierzony składnik szerszej całości),

Uważne, ciche dzieci, hałaśliwa, dumna, nieposkromiona ulica,

Niski, chrapliwy ton wirującego kamienia, lekko przyciskane

ostrze,

Sypiący się, opadający, rozpryskujący się złoty deszcz,

Iskry spod koła [podkr. - A.N.] ${ }^{33}$.

Postawa Miłosza wobec wielkiego miasta (w odróżnieniu od mniejszych miast, takich jak Wilno) była wprawdzie znacznie bardziej ambiwalentna (warto porównać wiersze Whitmana z Miłoszowskim opisem Megalopolis w części piątej poematu Gdzie wschodzi stonce $i$ kędy zapada), ale obu poetów łączy intuicja, że doświadczenie pełni zakłada przynależność do jakiejś wspólnoty (albo przynajmniej wymaga aktualizacji potencjalnej przynależności do niej; dzieje się tak przypadkowo). Jakieś „ja” patrzy na starego szlifierza i równocześnie widzi obserwujące go dzieci. Razem „my” stanowimy „gromadkę”, „niezamierzony składnik szerszej całości”, do którego wchodzi jeszcze sam Miłosz jako tłumacz wiersza Whitmana oraz czytelnik Nieobjętej ziemi, któremu „ziemia”, dzięki tej podwójnie zapośredniczonej sytuacji komunikacyjnej (Miłosz powiedziałby: w podwójnej „przeróbce” $\left.{ }^{4}\right)$, zdaje się coraz bardziej rozszerzać. „Płynność” jaźni została na chwilę „zatrzymana”, jednakże właśnie dzięki tej istocie ludzkiej egzystencji (jest ona $\mathrm{z}$ „uogólniającego” punktu widzenia logiki aporetyczna $\left.{ }^{35}\right)$ „moje” doznanie kawałka

33 C. Miłosz, Iskry spod koła, w: Wiersze, t. 4, s. 41.

34 Zob. niżej, s. 226-227.

35 Stanowi to również temat słynnego wiersza Wisławy Szymborskiej Ludzie na moście: „Czółno płynie bez ruchu./ Ludzie na moście biegną/ ściśle tam, co przed chwilą” (W. Szymborska, Ludzie na moście, w: Wiersze wybrane, Kraków 
rzeczywistości „tu i teraz” jest przekazywalne (sobie i innym). W odróżnieniu od Miłosza Whitman nie potrzebuje tu żadnych koncepcji explicite religijnych albo metafizycznych, takich jak „obcowanie świętych”, które w Gdzie wschodzi stońce $i$ kędy zapada współtworzy strukturę poematu (w Nieobjętej ziemi koncepcja ta wraca tylko w cytatach i epigrafach ${ }^{36}$ ).

Zadanie poezji polega więc na konstruowaniu całości artystycznych, których konkretyzacja umożliwia czytelnikowi uczestnictwo we wspólnocie. Wprawdzie ukonstytuowanie tej wspólnoty przez wspólny odbiór dzieła (jak w przypadku poezji ludowej lub tyrtejskiej albo pieśni kościelnej - tak się działo w może „fikcyjnej” epoce „poezji naiwnej”, postulowanej przez Fryderyka Schillera) okazuje się nadal niemożliwe. Konkretyzacja tekstu pozostaje aktem jednostkowym, przedstawiającym wyobcowanie podmiotu z pełni bytu jako jego „naturalną”, czyli „daną" mu formę istnienia. Ale owa jednostkowość aktu odbioru, odzwierciedlająca jednostkowość ludzkiej egzystencji w epoce niewiary i braku wyobrażeń o „życiu po śmierci” ${ }^{37}$, uobecnia potencjalną wspólnotę, która znalazła odbicie w tekście Nieobjętej ziemi. Właśnie dlatego ten tomik wykracza już poza formę poematu hybrydycznego. Ryszard Nycz wspomniał w związku z właściwościami konstrukcyjnymi tego rodzaju tekstów o odrodzeniu formy sylwicznej $3^{8}$. Nieobjęta ziemia jest w pewnym sensie kolejnym przykładem „sylwy współczesnej”, tyle że jej istotę można określić jedynie w kontekście specyficznej sytuacji podmiotu nowoczesnego mającego potrzeby religijne, lecz pozbawionego pewności dogmatycznej. Podmiot ten nie poddaje się „bramom ciemności”, które „tyle energii wkładają w tępienie wszystkiego, co boskie" ${ }^{39}$, ponieważ przeżywa swą więź z Innym za pośrednictwem indywidualnego obcowania $\mathrm{z}$ pewnymi artefaktami wskazującymi na wspólnotową istotę bycia czło-

2002, s. 281), tyle że tu podmiot mówiący, przekładając dzieło malarza buntownika, Hiroshige Utogawy, na dyskurs poetycki, nie uczestniczy w sytuacji lirycznej w pierwszej osobie. Niemniej trudno nie zauważyć, że znaczenie tego wiersza zawiera się właśnie w relacji między poet(k)ą, która posługuje się słowami znikającymi w czasie, a zatem niezdolnymi otworzyć równoczesność obrazu, i malarzem, odtwarzającym istotę ludzkiej egzystencji za pośrednictwem medium niezdolnego ująć jej przemijalność. Właśnie owa niesymetryczna relacja między poezją a malarstwem zrealizowana poprzez chwilową wspólnotę między „Szymborską” a „Hiroshigem” oddaje aporetyczność ludzkiej egzystencji.

${ }^{36}$ Por. C. Miłosz, Wiersze, t. 4, s. 127 (epigrafy z Corpus Hermeticum).

37 Por. C. Miłosz, Wiersze, t. 4, s. 74.

$3^{8}$ Nycz wrócił do tej koncepcji w Literaturze jako tropie rzeczywistościzob. R. Nycz, op.cit., s. 163-167.

39 C. Miłosz, Wiersze, t. 4, s. 75. 
wiekiem. Poetykę „wspólnotową” w Nieobjętej ziemi kształtuje obecność na poziomie tekstu różnego rodzaju takich artefaktów, jak na przykład wspomniane już epigrafy, ale też obrazy (Ogród ziemskich roszkoszy i notatka o siedemnastowiecznym malarzu holenderskim Fransie Poscie, który malował brazylijskie krajobrazy wzruszające kontrastem „pomiędzy ziemią i grupką ludzi, dawno umarłych" $\left.{ }^{40}\right)$. Szczególna rola przypada tłumaczonym przez Miłosza (i przedstawionym właśnie jako przekłady) utworom, które opisują i realizują ludzką kondycję nazywaną przez Whitmana en masse. Mamy tu więc do czynienia $\mathrm{z}$ intertekstualnością jako świadomie ujawnionym elementem tekstu (na wcześniejszych etapach twórczości Miłosza, np. w Traktaciepoetyckim lub w wierszu Nie więcej, w którym został zawarty niezbyt wierny opis obrazu weneckiego malarza Vittore Carpaccia, obecność artefaktów była najczęściej ukryta).

We wspomnianym eseju z Widzeń nad Zatoka San Francisco Miłosz podkreśla, że nie należy kondycji en masse mylić $\mathrm{z}$ „rozpłynięciem się w masie”. Każdy człowiek jest bowiem w pewnym sensie „Każdym” (w angielskim przekładzie eseju: Everyman) i należy do „zbiorowiska ludzkiego w ruchu”, składającego się z takich samych - ale jednak innych - Każdych. Dzięki przekładom wierszy Whitmana, wyrażających sytuację człowieka jako części takiej właśnie zbiorowości, potencjalna wspólnota między Czesławem Miłoszem a Waltem Whitmanem przeszła w akt. Miłosz, przekładając wiersze Whitmana i umieszczając je w Nieobjętej ziemi, stworzył coś, co można by słowami amerykańskiego wieszcza określić jako „niezamierzony składnik szerszej całości”. Mamy tu wprawdzie jeszcze do czynienia z czymś w rodzaju „galerii lustrzanej” (zob. Osobny zeszyt), ale owe odbicia „przypadkowych” momentów aktualizacji wspólnoty międzyludzkiej udostępniające „nam” (albo raczej „komuś konkretnemu", który właśnie jako jednostka okazuje się Everymanem, istniejącym en masse) kiedyś widziane, lecz obecnie minione kawałki rzeczywistości, obejmują coraz szersze obszary bytu. Okoliczność, że jako odbicia owe kawałki stwarzają efekt przypominający Derridiańską mise en abyme, nie podważa źródłowości doświadczenia „mojego” obcowania z innymi jaźniami. Whitman patrzy z dziećmi na starego szlifierza i „równocześnie” widziany jest przez tłumaczącego jego zapis tej "niezamierzonej” wspólnoty Miłosza, któremu przygląda się „równocześnie” (w „innej przestrzeni”) czytelnik Nieobjętej ziemi. Odbiór artefaktu powinien tu być równoznaczny z egzystencjalną potrzebą 
stworzenia nowej formy, nowego dzieła, choćby w postaci interpretacji starego. Z punktu widzenia Miłosza - autora Nieobjętej ziemi - owa niezbyt typowa odmiana wspólnoty pozornie polegająca na mechanizmie cofnięcia się $\mathrm{w}$ nieskończoność stanowi właśnie paradoksalny dowód na istnienie Boga. Również tę prawdę sformułował Miłosz w Nieobjętej ziemi, komentując (prozą) fragment z powieści George'a Orwella Rok 1984 i dopowiadając jej istotny sens:

- „Nie jesteś ty metafizykiem, Winston” - powiedział. - „Do tej chwili nigdy nie zastanawiałeś się, co znaczy istnienie. Wyrażę się dokładniej. Czy przeszłość istnieje konkretnie, w przestrzeni? Czy jest gdziekolwiek miejsce, świat ciał stałych, gdzie przeszłość dalej się odbywa?”

„Nie".

„Więc gdzie przeszłość istnieje, jeżeli istnieje?”

„W dokumentach. Zostaje zapisana”.

„W dokumentach, I?”

„W umyśle. W ludzkich pamięciach”.

„W pamięci. Bardzo dobrze. My, Partia, kontrolujemy dokumenty i kontrolujemy wszelką pamięć. A więc kontrolujemy przeszłość, czy nie tak?”

[komentarz Miłosza]

Trudno zaprzeczyć. Jakakolwiek rzeczywistość istnieje dla nas tyle tylko, o ile jest widziana, czyli tym samym poddana operacji umysłu. Cokolwiek nas otacza, trafia do nas w przeróbce pojęć, czyli mowy - mówionej, pisanej, ale obrazkowej. Tym bardziej, co minęło, nie jest nam dostępne inaczej niż w podwójnej przeróbce, jakiej poddał to umysł kiedyś i poddaje teraz. W innej postaci przeszłość nie istnieje. Kto utrzymuje inaczej, twierdzi po prostu, że nie dający się objąć kalejdoskop czasu w każdej swojej ćwierci sekundy jest obecny w jakimś nad-umyśle, który przeszłość, teraźniejszość i przyszłość ogląda równocześnie. Czyli wierzy w Boga. Taki zdaje się być fundament prawdy obiektywnej, której szukał agnostyk Orwell ${ }^{41}$.

Fragment ten to kolejna wypowiedź dyskursywna, która performatywnie (przez dialog z minioną "prawdziwą obecnością", której na imię Orwell) oraz przez paradoks (Miłosz chce - nie jest to na pewno zgodne $\mathrm{z}$ intencją samego Orwella ${ }^{42}-$ unaocz-

${ }_{41}$ C. Miłosz, Wiersze, t. 4, s. 79.

$4^{2}$ Miłoszowska wspólnota czasami wyklucza ludzi, zwłaszcza „mistrzów negatywności”. Miłosz stosuje w tym celu różne strategie: od otwartego 
nić egzystencjalną konieczność wiary w Boga) realizuje wspólnotową istotę bycia człowiekiem.

\section{ARENT VAN NIEUKERKEN \\ Czesław Milosz and Walt Whitman: translation as an authentic presence}

Miłosz's later poetry attempts to overcome the (post)modernist gap between the author as a textual effect and the subject of autobiography. An important stage on this road was his poetry book (in fact, a long poem in its own right) Nieobjęta ziemia [Unattainable Earth]. Its form is clearly dialogical. The collection mixes authorial poems with various examples of "heteroglossia". Particularly striking is the prominent presence of Walt Whitman's poetry. Whitmanian poetics assume that fully experiencing reality presupposes the existence of a community. The task of poetry consists in conceiving artistic structures that, when they are "concretized", allow the reader to participate in such a community. Nieobjęta ziemia tries to come to terms with the Whitmanian challenge. The poetical subject in this somewhat modified example of the modern "sylva rerum" experiences its link with the "other" by an individual reception of artifacts that point to the communal essence of humanity. Nieobjetta ziemia, realizing community in the field of poetics "performatively", incorporates these artifacts into the text. Particularly important seems to be the role played by poems translated by Miłosz himself (they are explicitly labeled as translations), and that represent the human condition called by Whitman "en masse".

Keywords: Czesław Miłosz, Walt Whitman, modernism, postmodernism.

\footnotetext{
Arent van Nieukerken - doktor, wykłada literaturę polską w Katedrze Slawistyki Uniwersytetu Amsterdamskiego. Jest autorem kilku książek oraz około 60 rozpraw i tekstów eseistycznych dotyczących literatury polskiej i komparatystyki. Najważniejsze publikacje: Ironiczny konceptyzm (1998) i Perspektywiczność sacrum (2007). Zajmuje się przede wszystkim literaturą modernizmu i romantyzmu. Jest również tłumaczem literackim. W ostatnich latach przełożył wybór prozy Cypriana Norwida (m.in. Stygmat) i poemat Czesława Miłosza Gdzie wschodzi stońce i kędy zapada.
}

potępienia (,ja” w przypadku Larkina) aż po stworzenie pseudowspólnot przez sfałszowanie albo przynajmniej unieszkodliwenie autentycznej intencji nielubianego poety (takie raczej jednostronne „dialogi” nawiązał np. z Lowellem i zwłaszcza - z Różewiczem). 